\begin{tabular}{|l|l|l||}
\hline \multicolumn{2}{|c|}{ PublisherInfo } \\
\hline \hline PublisherName & $:$ & BioMed Central \\
\hline \hline PublisherLocation & $:$ & London \\
\hline \hline PublisherImprintName & $:$ & BioMed Central \\
\hline \hline
\end{tabular}

\title{
Benzo[a]pyrene downregulation of BRCA1
}

\begin{tabular}{|l|l|l||}
\hline \multicolumn{2}{|c||}{ ArticleInfo } \\
\hline \hline ArticleID & $:$ & 3660 \\
\hline \hline ArticleDOI & $:$ & $10.1186 /$ bcr-1999-66638 \\
\hline \hline ArticleCitationID & $:$ & 66638 \\
\hline \hline ArticleSequenceNumber & $:$ & 26 \\
\hline \hline ArticleCategory & $:$ & Paper Report \\
\hline \hline ArticleFirstPage & $:$ & 1 \\
\hline \hline ArticleLastPage & $:$ & 3 \\
\hline \hline & $:$ & RegistrationDate : 1999-11-11 \\
ArticleHistory & $:$ & OnlineDate $:$ 1999-11-11 \\
\hline \hline ArticleCopyright & $:$ & Current Science Ltd1999 \\
\hline \hline ArticleGrants & $:$ & \\
\hline \hline ArticleContext & $:$ & 1305822 \\
\hline \hline
\end{tabular}




\section{Keywords}

Aromatic hydrocarbon receptor, benzo[a]pyrene, BRCA1, sporadic breast cancer

\section{Introduction}

Polycyclic aromatic hydrocarbons (PAHs) are ubiquitous contaminants found in tobacco smoke, industrial pollution, coal tar and car exhaust. The PAH benzo[a]pyrene (B[a]P), a classic DNAdamaging carcinogen found in high concentrations in tobacco smoke, displays a high affinity for the aromatic hydrocarbon receptor (AhR). Population studies have documented that smokers have more PAH-DNA adducts than do non-smokers, and suggest a potential correlation between tobacco smoking and the development of breast cancer.

\section{Aims}

To investigate the effects of PAHs on BRCA1 expression in breast and ovarian cancer cell lines.

\section{Comments}

Any association between tobacco smoking and breast cancer risk is controversial, with reports indicating that smoking may confer a protective effect due to an anti-estrogenic effect, as well as an increased risk because of a direct carcinogenic action. The evidence here is that $\mathrm{B}[\mathrm{a}] \mathrm{P}$, a known carcinogen found at high levels in tobacco smoke, may suppress the stimulatory effect of estrogen on expression of BRCA1 in human breast cancer cells. Disruption of BRCA1 expression by B[a]P, possibly preventing its participation in the repair of DNA damage, implicates it and its metabolite BPDE as a putative risk factor in sporadic breast cancer. Molecular studies such as these are important in elucidating the role of xenobiotics in the etiology of breast cancer, although much work remains to be done to reconcile the conflicting epidemiological data.

\section{Methods}


BRCA1 expression was investigated in estrogen receptor (ER)-positive breast MCF-7 and ovarian BG-1 cell lines, and ER-negative breast MDA-MB-231 and HBL-100 cell lines. BRCA1 mRNA expression was measured by the ribonuclease protection assay and semi-quantitative reverse transcriptase polymerase chain reaction (RT-PCR). BRCA1 protein expression was determined using western blot analysis with an anti-BRCA1 antibody.

\section{Results}

$\mathrm{B}[\mathrm{a}] \mathrm{P}$ exposure reduced $B R C A 1$ transcripts in the ER-positive MCF-7 and BG-1 cell lines in a dosedependent and time-dependent fashion, after both acute and chronic exposure. Loss of BRCA1 mRNA was paralleled by down regulation of BRCA1 protein. Exposure of the cells to the reactive metabolite of B[a]P,7r,8t-dihydroxy-9t,10t-epoxy-7,8,9,10-tetrahydrobenzo[a]pyrene (BPDE) also inhibited BRCA1 mRNA expression in ER-positive cells. A similar decrease in $B R C A 1$ expression was not seen in the ER-negative cell lines MDA-MB-231 and HBL-100. Benzo[e]pyrene (B[e]P), which has a low affinity for the AhR, showed no influence on BRCA1 in MCF-7 cells. The halogenated aryl hydrocarbon 2,3,7,8-tetrachlorodibenzo-p-dioxin (TCDD), which has a high affinity for the AhR, but is not metabolized, also had no effect on BRCA1 levels.

\section{Discussion}

Previous reports have documented downregulation of $B R C A 1 \mathrm{mRNA}$ in human breast and ovarian cancer cells by DNA-damaging and cytotoxic agents, including doxorubicin and ultraviolet radiation. Here, evidence is presented for a decrease in $B R C A 1$ expression due to $\mathrm{B}[\mathrm{a}] \mathrm{P}$ and its reactive metabolite in ER-positive, but not ER-negative, breast and ovarian cancer cell lines. Involvement of the AhR pathway implicates the receptor as a negative transcription factor.

\section{References}

1. Jeffy BD, Schultz EU, Selmin O, Gudas JM, Bowden GT, Romagnolo D: Inhibition of BRCA1 expression by benzo[a]pyrene and its diol epoxide. Mol Carcinog. 1999, 26: 100-118. 